Journal Of Association of Arab Universities For Tourism and Hospitality

Volume 15 - December 2018 -- (special issue) Page : ( 63- 73 )

\title{
The Perception of Tour Guides of Diversifying Destination Images: The Case of Egypt
}

Rania Moustafa Abdelrahman

Faculty of Tourism and Hotel Management - Suez Canal University

\begin{abstract}
Egypt has long been branded as a cultural destination possessing a treasure of antiquities ranging from pharaonic, Islamic and Greco- Roman relics. However, Egypt has made some attempts to diversify this cultural image. Hence, the aim of this research paper is to trace back the implications of this promotional shift through testing the perception of the Egyptian tour guides. A questionnaire was designed to examine the perception of these tour guides since the official introduction of the new diversified image of Egypt. The tour guides were asked some questions to test their perception on the new projected image of the destination. The results drawn from these questions were analyzed using the descriptive statistical approach. The research finally suggested some recommendations, as well as implications for future research that should be carefully considered by tourist promotion Authorities in Egypt, as well as any other tourist destination aiming for diversifying its tourist base to cater for multiple tourist segments.
\end{abstract}

Key words: product diversification, destination image, tour guides.

\section{Introduction}

The image of Egypt has always been reflecting the cultural product of the destination until the sixties of the past century when the destination attempted to modify this image by adding the recreational product to the cultural one. These early attempts were represented in establishing three hotels to cater for beach tourism over the North Western coast on the Mediterranean, on the Gulf of Suez and in Hurghada respectively. However, these attempts paused due to the war in 1967and lasted until the outbreak of the 1973 war. Then the state's attempt to create a new recreational product was resumed in more organized and scientific manner in the early eighties. Particularly, in 1982, when Egypt was being promoted under the slogan ''Egypt is not only monuments', The major aim of this campaign was to create a new tourist product so as to relieve the pressure on the famous cultural sites of the destination on one hand and to diversify the tourist image of the destination on the other hand. Nonetheless, all the campaigns executed since the very early attempts to diversify the tourist product of Egypt was a cause rather than an effect. It means that the main motivation of the image shift was primarily causal. It was either due to political reasons as to emphasise the sovereignty of Egypt over the Sinai Peninsula after the 1973 war or for environmental reasons to relieve the pressure on the cultural sites particularly in Upper Egypt after they had degraded due to the overload of tourist numbers on these sensitive archaeological sites. In other words, it was product oriented rather than customer oriented image shift strategy. This was due to the fact that the customer perception of the new diversified tourist image of Egypt was never tested through the targeted segments before embarking on the image shift campaigns. Accordingly, this research paper is mainly focusing on reviewing the image diversification strategies since the early eighties. Then asking a sample of the travel trade perceptions on the development of this image till present. This travel trade represented in a sample of tour guides who are experienced in conveying the new diversified tourist image of Egypt to its targeted segments. Accordingly, this research paper is mainly aiming at:

- Outlining the development of the diversified tourist image of Egypt since the early eighties.

- Examining the opinion of a selected sample of Egyptian tour guides on how they perceive the changing behavior of the targeted tourists after the diversification of the traditional cultural image of Egypt.

- Drawing some recommendations of a modified policy for a better projection of the new diversified tourist image of Egypt from the service providers' perspective.

\section{- Literature Review}

\section{Understanding Destination Image}

According to Valle et al. (2012), there are various ways of understanding and measuring the image of a place. Qu et al. (2011) argue that a destination image is influenced by cognitive and affective associations stored in visitors' memories. Other authors with similar perspectives refer to "image" as a dynamic construct, a set of beliefs concerning a particular product or experience (Kotler et al., 2006).

On the other hand, some authors associate image with more tangible factors. Pike and Ryan (2004) argue that the cognitive image is the sum of beliefs and knowledge about a destination, primarily focused on tangible physical attributes. Whereas, Valle et al. (2012) state that the cognitive image results from multiple cognitions or perceptions related to the knowledge of the specific attributes of a place. He also presents the cognitive image as being created on the basis of a number of attributes that correspond to resources, attractions, and the majority of tourism offers in the destination.

Moreover, the image of a destination is affectively and cognitively evaluated by a set of attributes comprising intangible and emotional values on the one hand and tourism resources (natural, cultural, infrastructural, product, and service) on the other. Therefore, understanding the type and characteristics of a destination is crucial in marketing as it makes it possible to define the appropriate marketing mix and to develop a destination brand designed to attract the designated target market (Paulo, 2013).

In the case of Egypt, the cognitive attributes that mainly influence tourists decision to choose Egypt as their holiday destination are the cultural attributes. These cultural attributes have built over the years a strong emotional bond with the tourist image of Egypt. However, the destination planners and policy makers in their planning for the diversification programme did not intend to change the traditional entrenched cultural identity of the destination. Rather they mainly aimed at consolidating this well established character by adding another product(s) to this image. Hence, it was a product modification strategy aimed at augmenting the overall cultural image of the destination by adding into it other products chief among them is the recreational product. This product augmentation process aimed at introducing the image of Egypt to multiple tourist segments, as well as to the existent cultural segment in order to make the destination appeal to diversified tourist segments.

Accordingly, the diversification of the tourist product of Egypt was a necessary strategy that is perceived by the policy makers as an important step in the development of the tourist image of the destination. Nevertheless, 
how the service providers represented in the Egyptian tour guides perceive the impact of this strategy on the demand side that is the targeted market segments in the different generating markets of Egypt is the major research question of this study. The tour guides have direct and first hand contact with tourists who come to visit Egypt since the actual steps were taken to diversify the tourist base of the destination in the eighties. Therefore, their perceptions are crucial in determining to what extent the diversification programme in Egypt had succeeded in changing the perceptions of its major tourist target segments to this new diversified image.

The Role of the Tour guide

Tour guides are cultural ambassadors who play a vital role in tourists' satisfaction and overall impressions, largely due to their close relationship with tourists. Many organizations and researchers differ in their definitions of tour guides and these guides' roles and responsibilities. The World Federation of Tourist Guide Associations (WFTGA) (2003) defines the tourist guide as:

\section{''[...] a person who guides visitors in the language of their choice and interprets the cultural and natural heritage of an area which person normally possesses an area-specific qualification usually issued and/or recognized by the appropriate authority'.}

This definition fully explains the job description of any tour guide and as such provides a basis for the interactions that take place between guide and tourist (Huang et al., 2010). In addition, different researchers use different terms to refer to tour guides in their research, and these include "tour leader", "local guide" or "tour coordinator" (Zhang and Chow, 2004). Furthermore, there are also variations in the types of roles that tour guides play. Regardless of these variations, however, scholars understand the role of the tour guide in providing a memorable tourist experience. It has been stated that tour guides, through their familiarity of a destination's attractions and culture and their communication competency, can transform tourists' visits from simple tours to memorable experiences. Moreover, guides act as intermediaries between travel destinations and their visitors as they are viewed to be responsible for the overall destination image tourists perceive (Sanz-Blas and Buzova, 2016). In other words, tour guides' communication may make or break a tour (Luoh and Tsaur, 2014).

In the case of Egypt, the tour guides have always been conveying the cultural identity of Egypt to its regular visitors. However, starting from the eighties, the destination policy planners began to attract tourists who favoured a combined tour of both culture and other aspects of tourism products chief among them is the recreational product in one tour termed as 'package tour".

\section{The Concept of Tourists' Behaviour}

It has been claimed that the concept of tourists' behaviour consists of tourists' judgement about the likeliness to revisit the same destination and the willingness to recommend the destination to others (Chen and Tsai, 2007). In the case of the diversification of the traditional cultural image of Egypt to offer a variety of tourist products and services. The main aim intended of this image shift was to influence the behaviour of the new targeted tourist segment(s) so as to find a multiple tourist product that would cater to the various and ever changing needs of the new tourist. Hence, secure a repeat visitor who would come again and recommend Egypt to his/her friends and relatives. However, the question that this paper poses is whether this image shift has succeeded in changing the intended tourist behaviour to the new image of Egypt as a tourist destination? This question will be discussed further in the following section.

\section{The impact of the new diversified tourist image of Egypt on the tourists' behaviour}

In general, people travel to particular destinations because these destinations satisfy a series of desires, such as escape from the daily routine, relaxation, and the opportunity to spend quality time with family or friends. These decisions, in turn, are stimulated and reinforced by the attributes of the chosen destination, such as beaches, cultural attractions, shopping facilities, and other attractions (Lee et al., 2012). From this perspective, these same authors point out that those different motivations are associated with different destinations, demonstrating the link between motivations and the image of a destination. However, the level of satisfaction of tourists with the services offered at the selected destination determines the probability of these tourists to make a repeat visit to this destination. In this respect, it has been maintained that satisfaction is one of the most important dimensions, as far as repeat choice behaviour is concerned (Oom do Valle et al., 2008). Satisfaction represents an antecedent of perceived service quality and satisfactory service quality experiences may lead a consumer to develop and modify his/her long-term global attitude (Ibid.). In the case of the new diversified image of Egypt, the destination policy planners and decision makers who are in charge of the diversification process supposed to have considered the motivational factors stated above that should induce their targeted tourists to select the new combination of cultural/recreational product projected to them. On the other hand, the level of satisfaction after the actual experience in the destination is the major research question of this current investigation. In other words, to what extent the Egyptian policy makers have succeeded in attracting the target tourist segments to the new diversified tourist image of the destination. This question will be answered via examining the level of satisfaction of these targeted tourists after their visit to the destination. It will be reflected through the Egyptian tour guides who accompanied them during their trip. The choice of tour guides instead of the tourists themselves was done for two main reasons. First, due to the inconvenience associated with asking the tourists about their level of satisfaction after visiting Egypt during the past 30 years. For the tracking of those tourists is not available. Second, the tour guides were found to be the best candidates to accomplish this process. This was due to the fact that the sample population selected for this study work as tour guides for an average of 15 to 20 years, hence in a much better position to reflect on their experience with the diversification process since its inception in the early eighties.

The following part delineates the methodological approach and the data collection tool adopted in this study.

\section{Methodology}

\section{Data Collection Method}

A quantitative research method was adopted in this study. Data were analyzed with the aid of Statistical Package for Social Sciences (SPSS) version 21 and Excel Spread Sheet in Office 2010. The data were collected through tour guides in Egypt. It was found that the total tour guides registered at the general syndicate of tour guides in Egypt amounted to 12000. Out of this number only 6000 were found to be effectively working as guides. Accordingly, a random sample of 370 of tour guides was selected for the study. A questionnaire based upon the Likert's 5-point scale. Questions were prepared to examine the tourist programme displayed for Egypt; the perception of tour guides of this programme; the category of tourists that visit Egypt after the introduction of the 
new diversified image of Egypt; the purchasing behaviour of tourists after the introduction of the new image, the suitability of the price of the new travel programme to the targeted tourists' needs; the social level of tourists and its impact on their travel behaviour, general expenditure patterns; attitudes and travel manners and level of awareness of the quality of the tourist product on offer; as well as the code of conduct and ethics that should be applied at the environmentally sensitive tourist sites after the introduction of the new tourist image. In addition, to examine the extent to which the new tourist is satisfied with his/her encounter with other tourists from different nationalities, as well as their encounter with the locals at the different tourist sites.

The respondents were asked to provide answers to each item that was measured by a 5-point Likert scale ranging from $1=$ "Yes, to a large extent" to $5=$ "Not at all" or "Did not change at all"'.

Results of the study

The experience of the Egyptian tour guides with the new diversified image of Egypt

Table (1) Years of Experience of Tour Guides with the new diversified image of Egypt

\begin{tabular}{|c|c|c|}
\hline Variables/Period & Frequency & \% \\
\hline Less than 10 years & 15 & 4.0 \\
\hline From 10 to less than 20 years & 31 & 8.4 \\
\hline More than 20 years & 324 & 87.6 \\
\hline & 370 & 100.0 \\
\hline
\end{tabular}

As table (1) shows a frequency of 324 of the study units with a percentage of $87.6 \%$ possess more than 20 years of experience working as tour guides in Egypt. Hence, they are able to trace back the development of the diversification programme since its inception in the eighties. Accordingly, they are eligible to convey the perception of the tourists who visited Egypt on the new image of the destination over the last 30 years, the main problem of the current study.

The Travel Programme of Egypt

Table (2) The Travel Programme of Egypt

\begin{tabular}{|c|c|c|}
\hline Travel Programme & Frequency & \% \\
\hline Purely Cultural & 15 & 4.1 \\
\hline Mostly Cultural & 336 & 90.8 \\
\hline Equally Cultural and Recreational & 19 & 5.1 \\
\hline & 370 & 100.0 \\
\hline
\end{tabular}

According to table (2) $90.8 \%$ of the study sample perceive's the travel programme of Egypt as mostly cultural. This means that, despite the introduction of other tourist products - among them is the recreational productwith the major cultural product, the majority of tourists still perceive the image of Egypt as mostly cultural as its main identity. Hence, the mental image of Egypt as a cultural destination still overrides its planned image as a destination offering multiple tourist products.

The general Perception of the Travel Programme of Egypt after the diversification of the image of the destination

Table (3) The Perception of the Travel Programme of Egypt since the introduction of the new diversified tourist image of the destination

\begin{tabular}{|c|c|c|}
\hline \multicolumn{3}{|l|}{ Perception } \\
\hline Choices from 1-5 & Valid & 370 \\
\hline $\begin{array}{l}\text { (1)Changed to a large extent } \\
\text { (2)Changed to some extent }\end{array}$ & Missing & 0 \\
\hline (3)Slightly changed & Mean & 3.17 \\
\hline (4)Did not change & Median & 1.00 \\
\hline (5)Did not change at all & Mode & 1.00 \\
\hline & Std. Deviation & .16 \\
\hline & Skewness & -.32 \\
\hline & Std. Error of Skewness & .25 \\
\hline & Kurtosis & -1.93 \\
\hline & Std. Error of Kurtosis & .50 \\
\hline & Range & 1.0 \\
\hline
\end{tabular}

In table (3), the sample of tour guides was asked about their opinion on whether the travel programme of Egypt has changed since the introduction of the new diversified image of the destination. The answers were provided on a 5 point likert scale, where 1 means; 'changed to a large extent'" up to 5 which means "' Did not change at all'". The mean of the answers to this question was 3.17, indicating that the majority of the sample see that the image falls between the choices "Slightly changed" and 'Did not change" with a mean near to the choice 'Slightly Changed' and a standard deviation of 0.16 . This means that the majority of the surveyed tour guides see that the travel programme did not undertake major changes since the introduction of the new diversified tourist image of Egypt. Hence, this could indicate that the Egyptian promotion Authority did not want to change the main cultural image of the destination. Instead, it only aimed at modifying its image to fit other products beside the major cultural product.

The new Category of tourists after the Diversification of the Destination Image

Table (4) The Category of tourists who visited Egypt after the introduction of the new diversified product to the destination.

\begin{tabular}{|c|c|c|c|c|c|}
\hline \multicolumn{2}{|c|}{ Category of tourists } & Frequency & Percent & $\begin{array}{c}\text { Valid } \\
\text { Percent }\end{array}$ & $\begin{array}{c}\text { Cumulative } \\
\text { Percent }\end{array}$ \\
\hline \multirow{4}{*}{ Valid } & $\begin{array}{l}\text { Price conscious category High spending } \\
\text { Category Environmentally sensitive category }\end{array}$ & 26 & 7.0 & 7.0 & 45.1 \\
\cline { 2 - 7 } & & 203 & 54.9 & 54.9 & 75.2 \\
\cline { 2 - 7 } & Total & 141 & 38.1 & 38.1 & 100.0 \\
\hline
\end{tabular}


As shown in table (4), tour guides were asked about their classification of the new tourist of Egypt. Three choices were provided; first; Price conscious category, second; high spending category and third; environmentally sensitive category. Most of the answers of the sample were centered on the $2^{\text {nd }}$ choice "' high spending category" with a percentage of $54.9 \%$ and a frequency of 203. This means that the tourists who are currently visiting Egypt are cultural visitors. This result agrees with the result of question no. 2, which refers, that the current travel programme of Egypt is mostly cultural.

The Purchasing Behaviour after the Diversification Programme

Table (5) the Purchasing Behaviour of Tourists after the introduction of the new diversified Image of Egypt

\begin{tabular}{|l|c|c|}
\hline \multicolumn{1}{|c|}{ Purchasing Behaviour } & Valid & $\mathbf{3 7 0}$ \\
\hline & Missing & 0 \\
\hline $\begin{array}{l}\text { (1)Changed to a large extent } \\
\text { (2)Changed to some extent }\end{array}$ & Mean & 2.37 \\
\hline (3)Slightly changed & Median & 1.12 \\
\hline (4)Did not change & Mode & 1.00 \\
\hline (5)Did not change at all & Std. Deviation & .12 \\
\hline & Skewness & -.22 \\
\hline & Std. Error of Skewness & .15 \\
\hline & Kurtosis & -1.13 \\
\hline & Std. Error of Kurtosis & .50 \\
\hline
\end{tabular}

In table (5), tour guides were asked whether the tourist's purchasing behavior has changed after the diversification of the tourist image of Egypt. The respondents were provided with a 5 point likert scale; where 1 refers to 'Changed to a large extent"' up to 5 which refers to "'Did not change at all'. The average of the answers has reached a mean of 2.37 which is strongly leaning towards the second choice that is "changed to some extent" with a standard deviation of 0.12 . This means that the overall purchasing behavior of tourists has not changed significantly since the introduction of the new diversified image of the destination. This finding supports the previous findings that the overall mental cultural identity of Egypt has not undertaken major changes since the introduction of the new diversified image of the destination.

Price Appropriateness of the new Product-Mix of Egypt

Table (6) The appropriateness of the Price of the Combined Tour offered to tourists to their needs after the introduction of the new diversified image of Egypt

\begin{tabular}{|l||c|c|}
\hline \multicolumn{1}{|c|}{ Price of the combined tour } & Valid & $\mathbf{3 6 8}$ \\
\cline { 2 - 3 } $\begin{array}{l}\text { (1)Yes, to a large extent } \\
\text { (2)Yes, to some extent }\end{array}$ & Missing & 2 \\
\hline (3)Slightly & Mean & 1.22 \\
\hline (4)No & Median & 0.92 \\
\hline (5)Not at all & Mode & 0.90 \\
\hline & Std. Deviation & .18 \\
\hline & Skewness & -.32 \\
\hline & Std. Error of Skewness & .15 \\
\hline & Kurtosis & -1.03 \\
\hline & Std. Error of Kurtosis & .50 \\
\hline
\end{tabular}

In table (6), the respondents were asked about the price of the combined tour offered to tourists after the introduction of the diversification programme and whether it suits their needs. The respondents were given a 5 point likert scale; where 1 means "Yes, to a large extent" up to 5 which means " Not at all". The average of the answers was 1.22 with a standard deviation of 0.18 . This means that most of the respondents believe that the price of the new combined tour was highly suitable to their needs, as most answers fall between the first choice "Yes, to a large extent" and the second choice "Yes, to some extent". Hence, this could mean that the current price of the combined tour on offer still very much affordable to the tourist who come to visit the destination who is also characterized by a high spending power, as most of the respondents see that the cultural tourist is still the main tourist who selects Egypt as his holiday destination.

The Social Level of Tourists after the Diversification of the Image of Egypt

Table (7) The Social level of Tourists after the introduction of the new Diversified Image of Egypt

\begin{tabular}{|l||c|c|}
\hline \multicolumn{1}{|c|}{ Social Level of Tourists } & Valid & $\mathbf{3 7 0}$ \\
\hline $\begin{array}{l}\text { (1)Changed to a large extent } \\
\text { (2)Changed to some extent }\end{array}$ & Missing & 0 \\
\hline (3)Slightly changed & Mean & 3.13 \\
\hline (4)Did not change & Median & 0.94 \\
\hline (5)Did not change at all & Mode & 0.98 \\
\hline & Std. Deviation & .19 \\
\hline & Skewness & -.22 \\
\hline & Std. Error of Skewness & .157 \\
\hline & Kurtosis & -1.03 \\
\hline & Std. Error of Kurtosis & .50 \\
\hline
\end{tabular}

Table (7) the researcher asked the sample whether the social level of the tourists who visit Egypt has changed since the introduction of the new diversified image of the destination. The respondents were given a 5 point Likert scale; where 1 means "Changed to a large extent" up to 5 which means " Did not change at all'. The mean of 
answers was 3.13 with a standard deviation of 0.19 . This means that the largest part of answers falls between the $3^{\text {rd }}$ choice that is "Slightly Changed" and the $2^{\text {nd }}$ choice "Changed to some extent'". This could indicate that the majority of the sample did not see that the social level of tourists has changed noticeably since the introduction of the new diversified image of the destination. This result agrees with all the previous results that the cultural tourist is still the major tourist that visits Egypt despite the inclusion of other tourist product(s) to the Egyptian packaged tour including the recreational product.

Relation between the social level and Travel behavior of tourists of the new image of Egypt

Table (8) The Relation between the Social level and the Travel Behaviour of tourists of the new combined image of Egypt

\begin{tabular}{|l|c|c|}
\hline \multicolumn{1}{|c|}{$\begin{array}{c}\text { Relation between Social level and } \\
\text { Travel Behaviour }\end{array}$} & Valid & $\mathbf{3 7 0}$ \\
\cline { 1 - 1 } $\begin{array}{l}\text { (1)Yes, to a large extent } \\
\text { (2)Yes, to some extent }\end{array}$ & Missing & 0 \\
\hline (3)Slightly & Mean & 2.37 \\
\hline (4)No & Median & 1.13 \\
\hline (5)Not at all & Mode & 1.00 \\
\hline & Std. Deviation & 2.32 \\
\hline & Skewness & -.32 \\
\hline & Std. Error of Skewness & .15 \\
\hline & Kurtosis & -1.33 \\
\hline & Std. Error of Kurtosis & .50 \\
\hline
\end{tabular}

In table (8), the sample of tour guides were asked whether the social level of the current tourists who visit Egypt has influenced their general travel behavior. The respondents were given a 5 point Likert scale, where 1 means "Yes, to a large extent" up to 5 which means "Not at all". The mean of the answers to this question has reached 2.37 with a standard deviation of 2.32 which is falling between the $2^{\text {nd }}$ choice "Yes, to some extent" and the $3^{\text {rd }}$ choice "Slightly". This result means that the social level of the current tourists has to some extent influenced their travel behavior after the introduction of the new diversified image of Egypt. This could indicate that the social class of the cultural tourist who is the major visitor of Egypt was reflected on his travel behaviour.

Relation between Social level and the Expenditure pattern of the new tourist of Egypt

Table (9) The Relation between the Social level and the General Expenditure Patterns of tourists of the new combined image of Egypt.

\begin{tabular}{|l|c|c|}
\hline \multirow{2}{*}{ Relation between Social level and General Expenditure Patterns } & Valid & $\mathbf{3 6 8}$ \\
\cline { 2 - 3 } & Missing & 2 \\
\hline $\begin{array}{l}\text { (1)Yes, to a large extent } \\
\text { (2)Yes, to some extent }\end{array}$ & Mean & 1.22 \\
\hline (3)Slightly & Median & 0.92 \\
\hline (4)No & Mode & 0.90 \\
\hline (5)Not at all & Std. Deviation & .18 \\
\hline & Skewness & -.32 \\
\hline & Std. Error of Skewness & .15 \\
\hline & Kurtosis & -1.03 \\
\hline & td. Error of Kurtosis & .50 \\
\hline
\end{tabular}

According to table (9), the informants were asked whether the social level of the current visitors to Egypt has influenced their general expenditure patterns. The informants were given a 5 point Likert scale, where 1 means "Yes, to a large extent"' up to 5 which means " Not at all". The mean of the answers has recorded an average of 1.22 and a standard deviation of 0.18 . This indicates that most informants' answers fall between the $1^{\text {st }}$ choice 'Yes, to a large extent" and the $2^{\text {nd }}$ choice "Yes, to some extent". This means that the social level of the current visitor of Egypt (the cultural tourist) is highly influencing his/her general expenditure pattern. This is due to the fact that this tourist is characterized by high spending power, which again ascertains that no other types or segments of tourists are effectively present to change this general attitude.

Relation between the Social level and Attitudes and Travel Manners of the new tourist of Egypt

Table (10) The Relation between the Social level and the attitudes and Travel Manners of tourists of the new combined image of Egypt

\begin{tabular}{|c|c|c|}
\hline $\begin{array}{l}\text { Relation between Social level and } \\
\text { Attitudes and Travel Manners }\end{array}$ & Valid & 370 \\
\hline & Missing & 0 \\
\hline $\begin{array}{l}\text { (1)Yes, to a large extent } \\
\text { (2)Yes, to some extent }\end{array}$ & Mean & 4.12 \\
\hline (3)Slightly & Median & 1.24 \\
\hline (4)No & Mode & 1.00 \\
\hline \multirow[t]{6}{*}{ (5)Not at all } & Std. Deviation & 1.12 \\
\hline & Skewness & -.22 \\
\hline & Std. Error of Skewness & .15 \\
\hline & Kurtosis & -0.93 \\
\hline & Std. Error of Kurtosis & .50 \\
\hline & Range & 1.00 \\
\hline
\end{tabular}


Table (10) shows the answers to the $10^{\text {th }}$ question: whether the social level of the current visitors to Egypt has influenced their attitudes and travel manners. The informants were given a 5 point Likert scale; where 1 means "Yes, to a large extent" up to 5 which means " Not at all". The mean of the answers has recorded an average of 4.12 with a standard deviation of 1.12 . This means that the majority of answers fall between the $4^{\text {th }}$ and $5^{\text {th }}$ choices that is "No" and "Not at all" respectively. Hence, this indicates that the sample of tour guides does not see that the social level of the current visitors to Egypt has influenced their attitudes and travel manners. In other words, the social level of the recent tourist complies with his/her attitudes and /or travel manners, i.e. he/she is still to a large extent a one type tourist that is the cultural tourist and not a mixed or multi type visitor i.e. different segments of tourists in one tour.

Relation between Social level and level of Quality of the new tourist product of Egypt

Table (11) The Relation between the Social level of tourists and the level of awareness of the quality of the tourist product of the new combined image of Egypt

\begin{tabular}{|c|c|c|}
\hline $\begin{array}{c}\text { Relation between Social level and level } \\
\text { of awareness of the quality of the new } \\
\text { tourist product }\end{array}$ & Valid & 370 \\
\hline & Missing & 0 \\
\hline $\begin{array}{l}\text { (1)Yes, to a large extent } \\
\text { (2)Yes, to some extent }\end{array}$ & Mean & 4.72 \\
\hline (3)Slightly & Median & 0.94 \\
\hline (4)No & Mode & 1.00 \\
\hline \multirow[t]{6}{*}{ (5)Not at all } & Std. Deviation & 0.02 \\
\hline & Skewness & -.25 \\
\hline & Std. Error of Skewness & .15 \\
\hline & Kurtosis & -0.92 \\
\hline & Std. Error of Kurtosis & .50 \\
\hline & Range & 1.00 \\
\hline
\end{tabular}

Table (11) shows the percentages of the answers: whether the social level of tourists who currently visiting Egypt has influenced their level of awareness of the quality or the real value of the tourist product on offer. The respondents were given a 5 point Likert scale; where 1 means ''Yes, to a large extent' up to 5 which means 'Not at all'. The answers have recorded a mean of 4.72 and a standard deviation of 0.02 . This indicates that most responses to this topic have referred to the $4^{\text {th }}$ and $5^{\text {th }}$ choices which recorded " No" and "Not at all' respectively with a high inclination to the $5^{\text {th }}$ choice "Not at all'. This further means that the social level of the current visitors to Egypt who are predominantly cultural tourists did not have any impact on their awareness of the real value of the tourist product on offer. Hence, this finding could infer that the cultural tourist of Egypt did not have a negative attitude or lack of awareness of the quality of the tourist product on offer. This result once more supports the opinion of the Egyptian tour guides in the previous questions that the tourist package of Egypt is still dominated by the cultural product despite the inclusion of other tourist products.

Categorization of the new tourist of Egypt as "Environmentally Sensitive Tourist"

Table (12) Categorization of the new tourist of Egypt as "Environmentally Sensitive Tourist",

\begin{tabular}{|l||c|c|}
\hline $\begin{array}{l}\text { Categorization of the new tourist of Egypt as } \\
\text { 'Environmentally Sensitive Tourist'" }\end{array}$ & Valid & $\mathbf{3 7 0}$ \\
\hline \multicolumn{1}{|c|}{$\begin{array}{l}\text { (1)Yes, to a large extent } \\
\text { (2)Yes, to some extent }\end{array}$} & Missing & 0 \\
\hline (3)Slightly & Mean & 1.12 \\
\hline (4)No & Median & 1.04 \\
\hline (5)Not at all & Std. Deviation & 1.00 \\
\hline & Skewness & 0.01 \\
\hline & Std. Error of Skewness & -.25 \\
\hline & Kurtosis & .15 \\
\hline & Std. Error of Kurtosis & -0.92 \\
\hline & Range & .50 \\
\hline
\end{tabular}

Table (12) shows the percentages of answers to the question about the opinion of the Egyptian tour operators on the possibility of categorizing the current visitors of Egypt as "Environmentally sensitive tourists". The respondents were provided with choices on a 5 point Likert scale; where 1 means "Yes, to a large extent" up to 5 which means 'Not at all'. The mean of the answers to this question has recorded 1.12 and a standard deviation of 0.01 . This means that the answers was falling between the $1^{\text {st }}$ and $2^{\text {nd }}$ choices which are "Yes, to a large extent" and "Yes to some extent"' respectively with a high reference to the $1^{\text {st }}$ choice "'Yes, to a large extent'". This finding denotes that the tour guides see that the current visitors to Egypt are highly sensitive to the environment of the tourist products. This finding also highly supports that the current visitor of Egypt is a cultural tourist who appreciates the environment and the sensitive nature of the tourist product, which is mostly characterizing the cultural product due to its fragile nature.

Understanding of the new tourist of Egypt of the "Code of Conduct" applied in the environmentally sensitive tourist sites 
Journal Of Association of Arab Universities For Tourism and Hospitality

Volume 15 - December 2018 -- (special issue) Page : ( 63- 73 )

Table (13) Understanding of tourists of the code of the conduct applied

in environmentally sensitive tourist products

\begin{tabular}{|l|c|c|}
\hline $\begin{array}{l}\text { Understanding of tourists of the code of } \\
\text { conduct applied in environmentally } \\
\text { sensitive tourist products }\end{array}$ & Valid & $\mathbf{3 7 0}$ \\
\cline { 1 - 3 } $\begin{array}{l}\text { (1)Yes, to a large extent } \\
\text { (2)Yes, to some extent }\end{array}$ & Missing & 0 \\
\hline (3)Slightly & Mean & 2.37 \\
\hline (4)No & Median & 1.13 \\
\hline (5)Not at all & Mode & 2.00 \\
\hline & Std. Deviation & -.32 \\
\hline & Skewness & .157 \\
\hline & Std. Error of Skewness & -1.33 \\
\hline & Kurtosis & .50 \\
\hline & Std. Error of Kurtosis & 1.00 \\
\hline
\end{tabular}

Table (13) shows the percentages of answers to the question on whether the new targeted tourist of Egypt understands the code of conduct that should be applied when visiting environmentally sensitive tourist products. The informants were provided with a 5 point Likert scale; where 1 means "'Yes, to a large extent'" up to 5 which means "Not at all". The mean of this question has recorded an average of 2.37 and a standard deviation of 2.32. This means that the answers were falling between the $2^{\text {nd }}$ and $3^{\text {rd }}$ choices that is "Yes, to some extent" and "Slightly" respectively with a strong leaning to the $2^{\text {nd }}$ choice. This means that the majority of the tour guides see that the current visitor of Egypt understands the code of conduct that should be applied in the environmentally sensitive tourist sites and hence will be able to apply it.

Understanding of Tourists to the "Code of Ethics" in the environmentally sensitive tourist sites

Table (14) Understanding of tourists to "the code of ethics" applied in environmentally sensitive tourist product

\begin{tabular}{|c|c|c|}
\hline $\begin{array}{l}\text { Understanding of tourists to the code of } \\
\text { ethics applied in environmentally } \\
\text { sensitive tourist products }\end{array}$ & Valid & 370 \\
\hline & Missing & 0 \\
\hline $\begin{array}{l}\text { (1)Yes, to a large extent } \\
\text { (2)Yes, to some extent }\end{array}$ & Mean & 1.21 \\
\hline (3)Slightly & Median & 0.93 \\
\hline (4)No & Mode & 1.00 \\
\hline \multirow[t]{6}{*}{ (5)Not at all } & Std. Deviation & 0.92 \\
\hline & Skewness & -.32 \\
\hline & Std. Error of Skewness & .15 \\
\hline & Kurtosis & -1.33 \\
\hline & Std. Error of Kurtosis & .50 \\
\hline & Range & 1.00 \\
\hline
\end{tabular}

Table (14) shows the result given by the study informants on the question of whether the new targeted tourist to Egypt understands the code of ethics that should be applied when visiting environmentally sensitive tourist products. The respondents were given a 5 point Likert scale where 1 means "Yes, to a large extent" up to 5 which means 'Not at all'. Most answers were falling between the $1^{\text {st }}$ and $2^{\text {nd }}$ choices that is "Yes, to a large extent'" and 'Yes, to some extent" respectively, with a mean of 1.21 and a standard deviation of 0.92 . This means that the Egyptian tour guides believe that the tourist who is currently visiting Egypt highly understands the code of ethics that should be applied at the environmentally sensitive tourist sites in Egypt. Hence, this finding supports the previous findings that the current visitor of Egypt is a cultural tourist who is highly educated on the sensitivity of the cultural sites and thus abiding by its procedures.

Relation between Quality of Service and Tourist Satisfaction

Table (15) The Relation between the Quality of service and Tourist Satisfaction (i.e. Value for Money)

\begin{tabular}{|c|c|c|}
\hline $\begin{array}{c}\text { elation between the Quality of service and Tourist } \\
\text { Satisfaction (i.e. Value for Money) }\end{array}$ & Valid & 370 \\
\hline $\begin{array}{l}\text { (1)Yes, to a large extent } \\
\text { (2)Yes, to some extent }\end{array}$ & Missing & 0 \\
\hline (3)Slightly & Mean & 2.81 \\
\hline (4)No & Median & 0.83 \\
\hline (5)Not at all & Mode & 1.00 \\
\hline & Std. Deviation & 1.16 \\
\hline & Skewness & -.12 \\
\hline & Std. Error of Skewness & .15 \\
\hline & Kurtosis & -0.93 \\
\hline & Std. Error of Kurtosis & .50 \\
\hline & Range & 1.00 \\
\hline
\end{tabular}

In table (15), the respondents were asked about whether the quality of the service offered to tourists who selected a combined tour to Egypt was satisfying their needs, i.e. whether the destination is offering them the best value for money. The respondents were given a 5 point Likert scale; where 1 means "Yes, to a large extent" up to 5 which means " Not at all". Most answers were pointing to the $2^{\text {nd }}$ and $3^{\text {rd }}$ choices "Yes, to some extent" and "Slightly" respectively, with more inclination to the $3^{\text {rd }}$ choice "Slightly" with a mean of 2.81 and a standard deviation of 
1.16. This means that the ongoing tourists are not fully satisfied with the quality of the service offered to them when compared with the price they paid for this service. This could also mean that either the price of the product was too high for the quality of the service or the price was too low which in turn negatively influenced the overall quality of the product on offer. However, the cultural product is a high quality product; that is a product that requires a bundle of good quality services associated with it such as high quality tour guiding, highly preserved monuments and artifacts, etc. Hence, this could mean that either the quality of these associated services was compensated for an affordable price or a high price was set for the tour package but did not present an equivalent quality of service in return.

Tourist Satisfaction with the Cost of the new Combined Package tour

Table (16) Tourists' Satisfaction with the overall Cost of the Combined Package Tour

\begin{tabular}{|c|c|c|}
\hline $\begin{array}{c}\text { Tourists' Satisfaction with the overall Cost of the } \\
\text { Combined Package Tour }\end{array}$ & Valid & 368 \\
\hline $\begin{array}{l}\text { (1)Yes, to a large extent } \\
\text { (2)Yes, to some extent }\end{array}$ & Missing & 2 \\
\hline (3)Slightly & Mean & 3.41 \\
\hline (4)No & Median & 0.93 \\
\hline (5)Not at all & Mode & 1.00 \\
\hline & Std. Deviation & 0.92 \\
\hline & Skewness & -.32 \\
\hline & Std. Error of Skewness & .15 \\
\hline & Kurtosis & -1.33 \\
\hline & Std. Error of Kurtosis & .50 \\
\hline & Range & 1.00 \\
\hline
\end{tabular}

In Table (16), the informants were asked for whether tourists are satisfied with the overall cost they paid for the combined package tour offered to them. The respondents were given a 5 point Likert scale; where 1 means "'Yes, to a large extent"' up to 5 which means " Not at all". The majority of the answers were pointing to the $3^{\text {rd }}$ and $4^{\text {th }}$ choices that is "Slightly" and "No" respectively with a mean of 3.41 and a standard deviation of 0.92 . This means that the current visitors to Egypt are barely satisfied with the overall cost of the travel package offered to them. Again this finding supports the previous result that the current tourists who visit Egypt are neither fully satisfied with the quality of service offered to them nor with its price.

Tourist's Satisfaction with their encounters with other tourists

Table (17) Tourists' Satisfaction with their encounters with other tourists from different nationalities

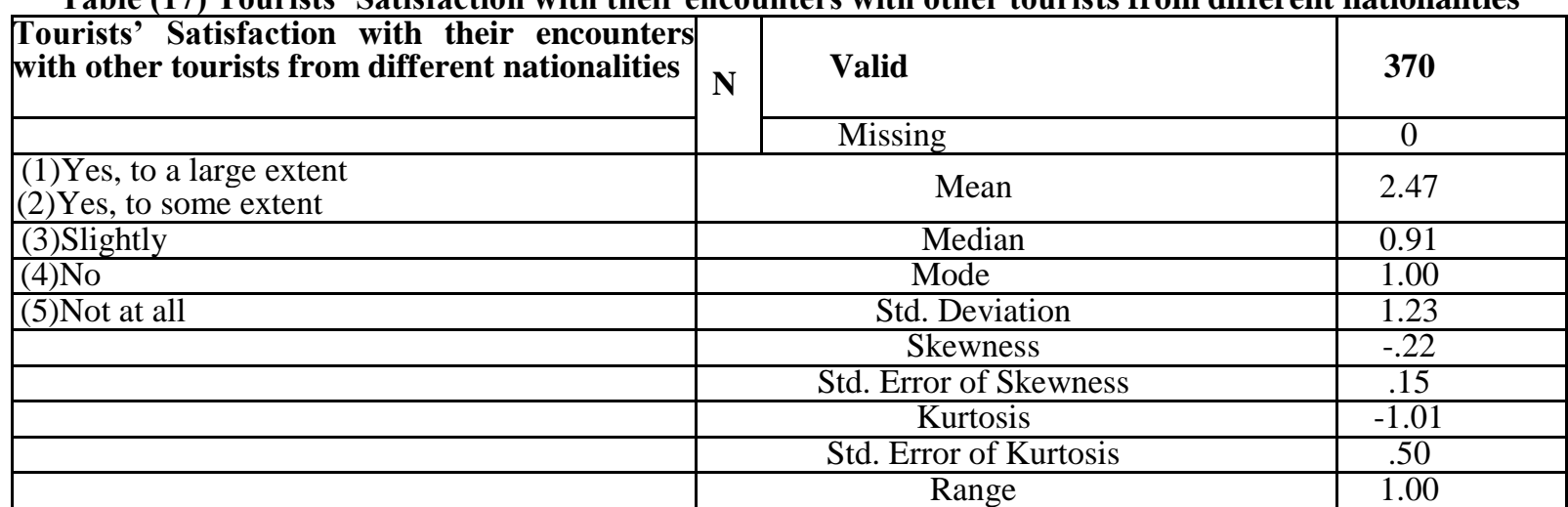

In table (17), tour guides were asked whether tourists currently visiting Egypt are satisfied with their encounters with other tourists from different nationalities and travel interests. The respondents were given a 5 point Likert scale; where 1 means " Yes, to a large extent" up to 5 which means " Not at all". Most responses to this question were referring to the $2^{\text {nd }}$ choice and $3^{\text {rd }}$ choices that is "Yes, to some extent" and "Slightly" respectively with a mean of 2.47 and a standard deviation of 1.23. This means that mixing tourists from different nationalities, cultures or backgrounds and travel interests do not act as an impediment for tourists to enjoy their travel experience at the destination. This could be an interesting finding that can induce the Egyptian Authorities to work harder on diversifying the tourist base of Egypt by including tourists from different nationalities and travel interests who could coexist without any presence of cultural sensitivity.

Tourist's Satisfaction with their encounters with Locals and its impact on their Travel Experience

Table (18) Tourists' Satisfaction with their encounters with locals and its impact on their overall travel experience

Tourists' Satisfaction with their encounters with locals and its impact on

1)Yes, to a large extent their overall travel experience

2)Yes, to some extent

3)Slightly

4)No

5)Not at all

\begin{tabular}{c|c|c|} 
& Valid & $\mathbf{3 7 0}$ \\
\cline { 2 - 3 } $\mathbf{N}$ & Missing & 0 \\
\hline Mean & 1.22 \\
\hline Median & 0.92 \\
Mode & 0.90 \\
\hline Std. Deviation & .18 \\
\hline Skewness & -.32 \\
\hline td. Error of Skewness & .15 \\
\hline Kurtosis & -1.03 \\
\hline Std. Error of Kurtosis & .50 \\
\hline Range & .00 \\
\hline
\end{tabular}


Table (18) shows the total percentages of the answers to the question on whether tourists are satisfied with their encounters with locals at different sites they visit and whether their encounters have influenced their overall travel experience. The respondents were given a 5 point Likert scale; where 1 means "Yes, to a large extent" up to 5 which means "Not at all". Most answers were pointing to the $1^{\text {st }}$ and $2^{\text {nd }}$ choices that is "Yes, to a large extent" and "Yes, to some extent" respectively with a mean of 1.22 and a standard deviation 0.18 . This indicates that the presence of locals at the tourist sites visited is highly preferable by tourists, as they enjoy their presence, which complements their satisfaction with the overall travel experience.

Tourist Understanding of the Ecological guidelines at the Environmentally Sensitive tourist sites.

Table (19) Understanding of tourists of the Ecological Guidelines offered to them at the Environmental Sensitive areas

\begin{tabular}{|c|c|c|c|}
\hline \multirow{2}{*}{\begin{tabular}{|l|}
$\begin{array}{l}\text { Understanding of tourists of the Ecological Guidelines } \\
\text { offered to them at the Environmental Sensitive areas. }\end{array}$ \\
\end{tabular}} & \multirow{2}{*}{$\mathbf{N}$} & \multirow{2}{*}{$\begin{array}{l}\text { Valid } \\
\text { Missing }\end{array}$} & \multirow{2}{*}{$\begin{array}{c}370 \\
0 \\
\end{array}$} \\
\hline & & & \\
\hline \begin{tabular}{|l} 
(1)Yes, to a large extent \\
(2)Yes, to some extent
\end{tabular} & & Mean & 2.73 \\
\hline (3)Slightly & & Median & 0.91 \\
\hline (4) No & & Mode & 1.00 \\
\hline \multirow[t]{6}{*}{ (5)Not at all } & & Std. Deviation & 1.22 \\
\hline & & Skewness & -.22 \\
\hline & & Std. Error of Skewness & .157 \\
\hline & & Kurtosis & -0.99 \\
\hline & & Std. Error of Kurtosis & .50 \\
\hline & & Range & 1.00 \\
\hline
\end{tabular}

In Table (19), the informants were asked whether tourists understand the ecological guidelines offered to them at the environmental sensitive areas and were positively interacting with it. The respondents were given a 5 point Likert scale; where 1 means "Yes, to a large extent" up to 5 which means "Not at all". Most answers ranged between the $2^{\text {nd }}$ and $3^{\text {rd }}$ choices that is "Yes, to some extent" and "Slightly" respectively with a strong inclination to "Slightly", with a mean of 2.73 and a standard deviation of 1.22. This shows that the tour guides believe that the current visitors understand the ecological instructions given to them at the sensitive areas and hence are abided by it. This once more supports the aforementioned finding that the majority of the tourists are cultural tourists.

Tourist's Satisfaction with the Services offered at the Environmental Sensitive tourist sites

Table (20) Tourists' Satisfaction with the Services offered to them at the Environmental Sensitive areas

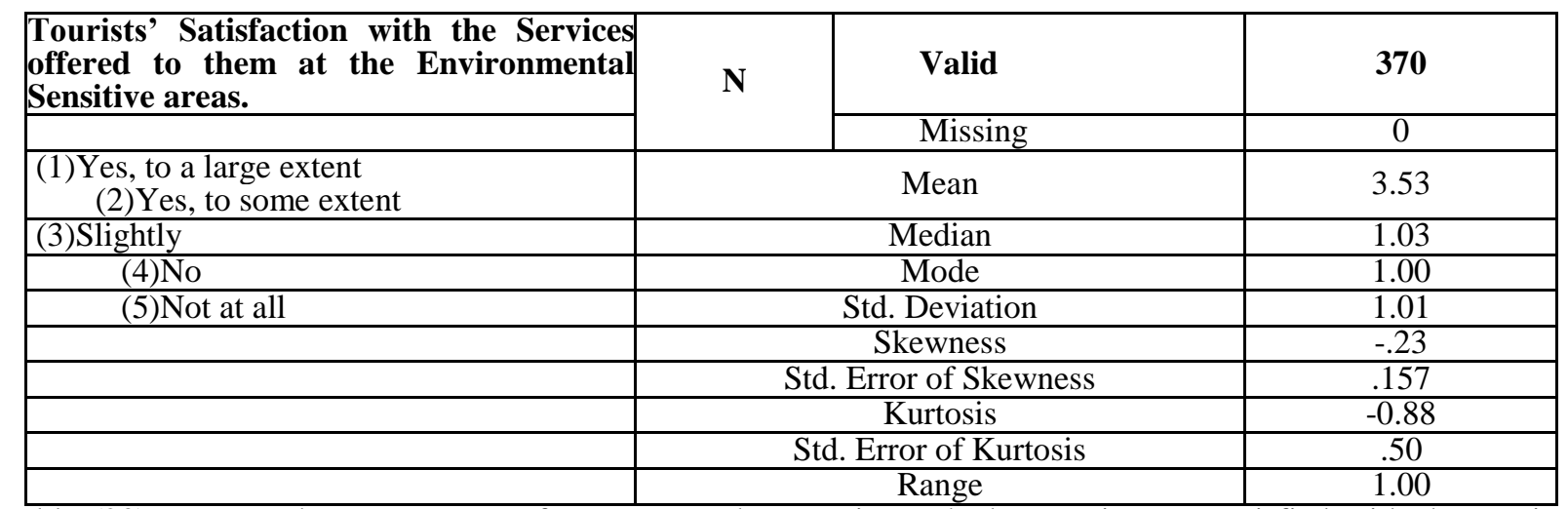

Table (20) presents the percentages of answers to the question: whether tourists are satisfied with the services offered to them at the environmental sensitive areas and hence are satisfied with their overall experience at these sites. The tour guides were given a 5 point Likert scale; where 1 means "Yes, to a large extent" up to 5 which means "Not at all". Most answers were pointing to the $3^{\text {td }}$ and $4^{\text {th }}$ choices that is "Slightly" and "No" respectively with a mean of 3.53 and a standard deviation of 1.01. This finding denotes that tourists are hardly satisfied with the overall services offered to them at the environmental sensitive areas in Egypt. This finding highlights a common perception given by the tour guides that is; although the current visitors of Egypt are predominantly cultural tourists, the level of service offered to them at their selected tourist sites is highly questionable. This means that however the cultural tourist is characterized by high spending and high education and is highly selective in his/her choices, his/her general level of satisfaction with the overall tourist experience in Egypt is not meeting his/her expectations. 
According to the aforementioned analysis, the researcher elicited some key findings of this study. They are as follows:

1. The tourist that selects Egypt, as a holiday destination is predominantly cultural tourist.

2. The travel programme offered to the visitors of Egypt did not undertake major changes since the introduction of the new diversified image of the destination.

3. Tourists that are visiting Egypt are from the high spending category of tourists.

4. The overall purchasing behavior of tourists has not changed significantly since the introduction of the new diversified image of the destination.

5. The social level of tourists visiting Egypt neither changed after the introduction of the new product-mix of the destination nor it affected their travel behavior, general expenditure patterns, attitudes and the quality of the tourist product on offer.

6. The visitors of Egypt understand the code of conduct and code of ethics that should be applied at the environmentally sensitive tourist sites.

7. The tourists who visit Egypt are not fully satisfied with the quality of the service offered to them when compared with the price they paid for this service.

8. The visitors of Egypt who selected a combined tour are highly interacting with tourists from different nationalities, as well as with the locals at different tourist sites. This could be one of the successful outcomes of the diversification programme by making tourists from different nationalities, and travel interests coexist without any presence of cultural sensitivity.

9. The visitors of Egypt are ecologically oriented and satisfied with the service offered at the environmentally sensitive areas. This indicates that these visitors are mostly cultural and Egypt's image is still mostly cultural despite the inclusion of other recreational products recently added to it.

\section{Conclusion and Recommendations}

According to the aforementioned results; the general perception of the impact of the diversification programme on the type of tourists who select Egypt as their travel destination is highly negative. This means that the diversification programme did not have any impact on the selection criteria of the current visitors of Egypt. The tour guides see these visitors as predominantly cultural and their travel behviour or attitude accordingly did not undertake significant changes since the introduction of the new diversified image of the destination.

Moreover, the guides see that the current travel programme of Egypt is mostly cultural where no other types of tourist products are evidently present with the original cultural product. This could mean that the Egyptian policy planners did not want to highlight the presence of the recreational product with the cultural one, as they did not want to change the cultural identity of the destination. Rather, they wanted to augment or consolidate its competitive cultural product by adding other types of tourist products, among them is the recreational product. On the other hand, this could also indicate that the sample population of tour guides only deal with tourists down the cultural sites and do not accompany them in their extended tour to the recreational sites; hence, they were not able to reflect their overall perceptions gained from tourists on the new combined product-mix of the destination.

Accordingly, the current study recommends the following:

- The Egyptian policy makers in the public tourism sector should increasingly highlight the new product- mix of Egypt as a part and parcel of the general image of the destination. Although the cultural identity of the country should be preserved, the new image was originally planned for consolidating and augmenting this image, not to override or change it.

- These other products added to the original cultural product could act as an alternative choice, particularly during crisis when the different acts of terrorism target the cultural asset of the destination.

- There should be effective channels of communication between the public sector image planning stakeholders and the travel trade represented by the tour guides in this study. This communication could be exemplified in channeling views and opinions of those tour guides on the planning of the new image of Egypt as they deal directly with the tourist who selects Egypt as his/her holiday destination. These views could be regulated and transferred through the tour operators who implement the travel programme.

- The tourism educational institutions in Egypt should also have a role in the diversification of the tourist product of the destination. They can design tourist curricula that include subjects for tour guiding such as special curricula for different tourist products in addition to the cultural product like subjects related to shopping tourism, safari tourism, desert tourism, diving tourism and the like.

- According to the above recommendation, these curricula will extend the role of the tour guide to accompany tourists in their extended travel package rather than only confining the tour guide's role to the cultural sites, hence they will have a positive role in the diversification of the tourist product of Egypt.

- The syndicate of the Egyptian tour guides should also participate in the diversification of the travel programme of Egypt by including new aspects of the diversified tourist product with the cultural product on the tour guiding license issued by the syndicate. These aspects may include safari tourism, diving tourism, environmental tourism, shopping tourism etc. where the tour guide will become entitled to work on these new aspects together with the cultural product, hence will have an effective role in the diversification of the tourist product of Egypt.

\section{Implications for Future Research}

Further research should be conducted on providing guidelines to the public tourist Authorities on how to include the travel intermediaries represented in tour guides and tour operators in the planning and branding of destination images. The travel intermediaries have a vital role in the marketing and quality of the service on offer to tourists, thus should posses a pivotal role in giving their feedback on how to better project the destination image to its targeted tourist segments. 


\section{References:}

- Beerli, A. and Martín, J.D. (2004). Tourists' Characteristics and the Perceived Image of Tourist Destinations: A Quantitative Analysis - A Case Study of Lanzarote, Spain, Tourism Management, Vol. 25, No. 5, pp. 623-636.

- Chen C and Tsai DC. (2007). How Destination Image and Evaluative Factors Affect Behavioral Intentions?, Tourism Management, Vol. 28, pp. 1115-1122.

- Cooper, C. and Hall, M. (2008). Contemporary Tourism: An International Approach, Elsevier, Oxford.

- Frías, D.M.; Rodríguez, M.A.; Castañeda, J.A.; Sabiote, C.M. and Buhalis, D. (2012). The Formation of a Tourist Destination's Image via Information Sources: the Moderating Effect of Culture, International Journal of Tourism Research, Vol. 14, pp. 437-450.

- Huang, S., Hsu, C.H.C. and Chan, A. (2010). Tour Guide Performance and Tourist Satisfaction: A Study of the Package Tours in Shanghai", Journal of Hospitality and Tourism Research, Vol. 34 No. 1, pp. 3-33.

- Kotler, P., Gertner, D., Rein, I., \& Haider, D. (2006). Marketing de Lugares -Como Conquistar Crescimento de Longo Prazo na América Latina e no Caribe, [Placement Marketing - How to achieve long-term growth in Latin America and the Caribbean] São Paulo, Brasil: Pearson Education do Brasil.

- Lee, H.A., Guillet, B.D., Law, R. and Leung, R. (2012). Travel Motivations and Travel Distance with Temporal Advance: A Case Study of Hong Kong Pleasure Travelers, Journal of Destination Marketing \& Management, Vol. 1, Nos. 1-2, pp. 107-117.

- Luoh, H.F. and Tsaur, S.H. (2014). The Effects of Age Stereotypes on Tour Leader Roles, Journal of Travel Research, Vol. 53, No. 1, pp. 111-123.

- $\quad$ Oom do Valle, P.; Correia, A. and Rebelo, E. (2008). Determinants of Tourism Return Behaviour, Tourism and Hospitality Research, Vol. 8, No. 3, pp. 205-219.

- Paulo, S. (2013). Branding de Destinos Turísticos de Cidade: a Imagem como Determinante para Consolidar o Posicionamento de Lisboa, [Branding of City Tourist Destinations: The Image as Determinant to Consolidate the Lisbon Positioning.] Master, Instituto Politécnico de Leiria, Peniche, Portugal.

- Pike, S. and Ryan, C. (2004). Destination Positioning Analysis through a Comparison of Cognitive, Affective and Conative Perceptions. Journal of Travel Research, Vol. 42, No. 4, pp. 333-342.

- Qu, H., Kim, L., \& Im, H. (2011). A Model of Destination Branding: Integrating the Concepts of the Branding and Destination Image, Tourism Management, Vol. 32, No. 3, pp. 465-476.

- Sánchez-Rivero, M. and Pulido-Fernández, J.I. (2012). Testing Heterogeneous Image in Cultural/Non-cultural Tourism Markets: a Latent Model Approach, International Journal of Tourism Research, 14, 250-268.

- San Martín H. and Rodríguez del Bosque I.A. (2008). Exploring the Cognitive-affective Nature of Destination Image and the Role of Psychological Factors in its Formation, Tourism Management, Vol. 29, No. 2, pp. 263-277.

- $\quad$ Sanz-Blas, S. and Buzova,D.(2016). Guided Tour Influence on Cruise Tourist Experience in a Port of Call: An eWOM and Questionnaire-Based Approach, International Journal of Tourism Research, Vol.18 pp:558566.

- Tasci, A.D.A.; Gartner, W.C. and Cavusgil, S.T. (2007). Conceptualisation and Operationalisation of Destination Image, Journal of Hospitality and Tourism Research, Vol. 31, No. 2, pp. 194-223.

- Valle, P., Mendes, J., \& Guerreiro, M. (2012). Residents' Participation in Events, Events Image, and Destination Image: A Correspondence Analysis, Journal of Travel \& Tourism Marketing, Vol. 29, No. 7, pp. 647-664.

- White C. (2004). Destination Image: To See or not to See, International Journal of Contemporary Hospitality Management, Vol. 16, pp. 309-314.

- World Federation of Tourist Guide Associations "WFTGA" (2003). In: http://www.wftga.org/touristguiding/what-tourist-guide , accessed in 30/9/2018.

- Zhang, H.Q., and Chow, I. (2004). Application of Importance-performance Model in Tour Guides' Performance: Evidence from Mainland Chinese Outbound Visitors in Hong Kong, Tourism Management, Vol. 25, No. 1, pp. 81-91.

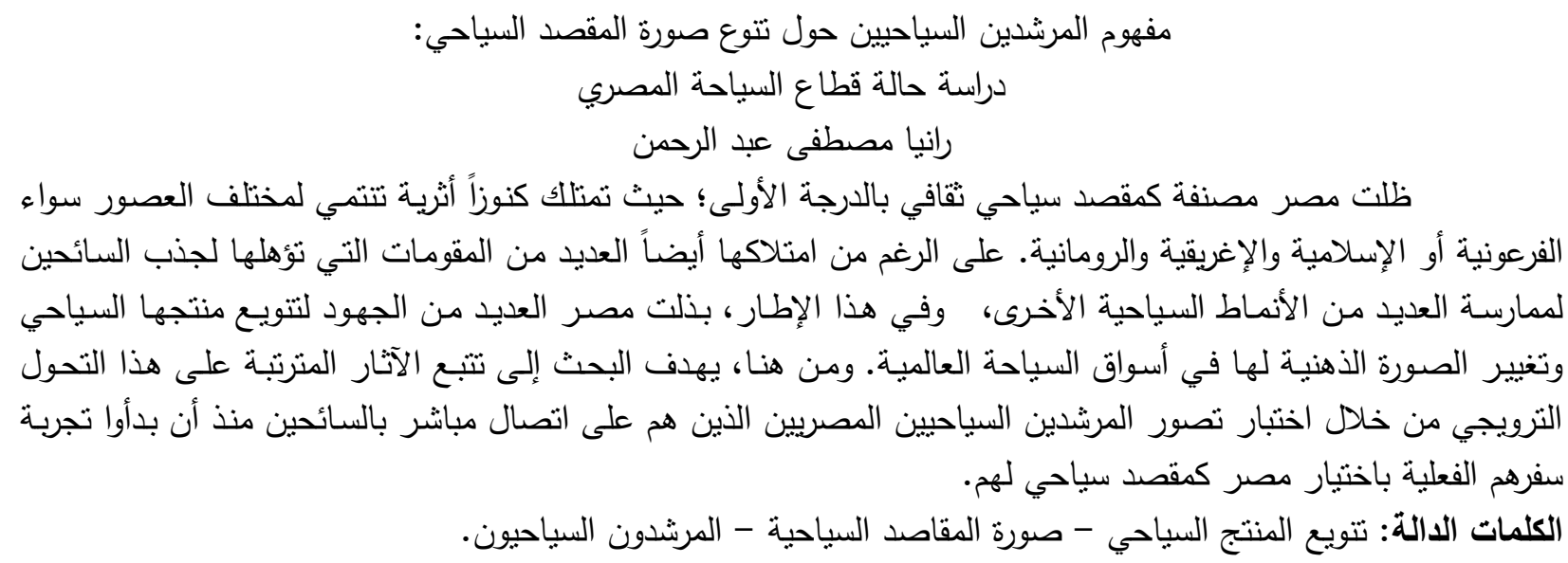

